\title{
ETHANOLIC FERMENTATION OF SUCROSE, SUGARCANE JUICE AND MOLASSES BY ESCHERICHIA COLI STRAIN KO11 AND KLEBSIELLA OXYTOCA STRAIN P2
}

\author{
Gervásio P. da Silva ${ }^{1 *}$; Elza F. de Araújo²; Daison O. Silva²; Walter V. Guimarães² \\ ${ }^{1}$ Departamento de Educação, Universidade do Estado da Bahia, Senhor do Bonfim, BA, Brasil; ${ }^{2}$ Departamento de \\ Microbiologia, Universidade Federal de Viçosa, Viçosa, MG, Brasil
}

Submitted: September 12, 2005; Returned to authors for corrections: September 29, 2005; Approved: October 18, 2005

\begin{abstract}
Escherichia coli KO11 and Klebsiella oxytoca $\mathrm{P} 2$ recombinants fermented sucrose to ethanol. In minimal medium with $2 \%$ or $12 \%$ added sucrose $\mathrm{KO} 11$ produced $75 \%$ and $41 \%$, respectively, of the maximum theoretical yield $(0.54 \mathrm{~g}$ ethanol/g sucrose). In Luria-Bertani (LB) broth with up to $8 \%$ sucrose, KO11 presented a $94-96 \%$ yield and with $12 \%$ sucrose, $\mathrm{KO} 11$ presented about $69 \%$ yield $(44.5 \mathrm{~g}$ ethanol $/ \mathrm{L}) . \mathrm{P} 2$ presented $55 \%$ of the theoretical maximum yield in minimal medium supplemented with $2 \%$ sucrose and $47 \%$ of the maximum in $12 \%$ sucrose. In LB broth with 2 or $4 \%$ sucrose, P2 presented 94-95\% of the theoretical maximum yield, which fell to $73 \%$ with $8 \%$ added sucrose $(31.4 \mathrm{~g}$ ethanol/L) and $58 \%$ with $12 \%$ sucrose $(37.5 \mathrm{~g} / \mathrm{L})$. Volumetric productivity in LB broth containing $2 \%$ sucrose was $0.41 \mathrm{~g} / \mathrm{L} / \mathrm{h}$ for $\mathrm{KO} 11$ and $1.1 \mathrm{~g} / \mathrm{L} / \mathrm{h}$ for P2, while in LB broth with $12 \%$ added sucrose, productivity was $0.96 \mathrm{~g} / \mathrm{L} / \mathrm{h}$ (KO11) and $1.4 \mathrm{~g} / \mathrm{L} / \mathrm{h}$ (P2). During fermentation of sugar cane juice by $E$. coli $\mathrm{KO} 11$ and $K$. oxytoca $\mathrm{P} 2$ produced $39.4 \mathrm{~g} / \mathrm{L}$ and $42.1 \mathrm{~g} / \mathrm{L}$ ethanol when supplemented with $0.5 \%$ yeast extract, micronutrients and thiamine. In sugar cane juice supplemented with LB broth ingredients, KO11 ethanol fermentation was inhibited with production of only $23.0 \mathrm{~g}$ ethanol/L, while $\mathrm{P} 2$ produced $44.2 \mathrm{~g} /$ L. Ethanol production by KO11 and P2, respectively, in sugarcane juice was a) 25.3 and $30.2 \mathrm{~g} / \mathrm{L}$ with $0.2 \%$ ammonium sulfate, b) 24.9 and $31.6 \mathrm{~g} / \mathrm{L}$ with ammonium sulfate and micronutrients, c) 25.6 and $37.5 \mathrm{~g} / \mathrm{L}$ with ammonium sulfate, micronutrients and thiamine. During molasses fermentation E. coli KO11 presented low ethanol production and high lactic acid production. K. oxytoca $\mathrm{P} 2$ produced $25 \mathrm{~g}$ ethanol/L in molasses diluted 10 -fold in water, with or without addition of $0.5 \%$ yeast extract, and $27.8 \mathrm{~g} / \mathrm{L}$ with addition of $\mathrm{LB}$ broth ingredients after $96 \mathrm{~h}$. $\mathrm{P} 2$ produced $24.5,26.9$, and $28.0 \mathrm{~g}$ ethanol/L in molasses diluted 10 -fold in vinasse, vinasse with $0.5 \%$ added yeast extract and with LB broth ingredients, respectively.
\end{abstract}

Key words: Escherichia coli KO11, Klebsiella oxytoca P2, Zymomonas mobilis, sucrose fermentation, ethanol fermentation

\section{INTRODUCTION}

Petroleum is the most widely used fuel source on the planet. Petroleum will undoubtedly be depleted since it is a non-renewable fossil fuel source. It is estimated that crude oil production will decline worldwide by 2010 , and become drastically reduced by 2050 (8). Brazil was compelled to search for new energy sources to substitute gasoline after the 1973 "petroleum crisis". The Brazilian "National Alcohol Program" (Proálcool) was created in
1975, with its main objective being to promote substitution of gasoline by ethanol as automotive fuel (6). Through Proálcool, Brazilian ethanol production grew from 556 million liters in 1975/ 76 to 11.4 billion liters in 1985/86, turning the country into one of the world's biggest ethanol producers and consumers.

Brazil developed a technology for motor combustion with ethanol and was the pioneer in large-scale use of alcohol as automotive fuel. In the 1980's, about $95 \%$ of the vehicles produced in the Brazil were equipped with alcohol combustion

*Corresponding Author. Mailing address: Universidade do Estado da Bahia, Departamento de Educação, BR 407, Km 127, UNEB, Senhor do Bonfim, BA, Brasil. Telefax: (+5574) 3541-4013. E-mail: gpsilva@uneb.br 
motors. Currently, the majority of ethanol produced in Brazil is used as a gasoline additive, at a percentage of $24-26 \%$ (31). However, use of hydrated alcohol as automotive fuel is increasing currently because of the rising popularity of vehicles that can use alcohol as well as gasoline or their mixture in differing proportions (Flex fuel technology). Flex-fuel vehicles represented $58.9 \%$, gasoline engines $35.6 \%$ and alcohol engines $1 \%$ of all car sales in Brazil in July of 2005 (10).

Alcohol fuel presents several advantages over gasoline: alcohol combustion does not cause an increase in atmospheric $\mathrm{CO}_{2}$ concentration, and is less polluting than gasoline because alcohol produces less toxic substances and less gaseous emissions (26). Ethanol is a pure substance of known composition, whereas gasoline is a mixture of different compounds. Alcohol is also a more secure energy source because it is renewable $(11,23)$ and can be produced anywhere in the world from biomass.

In the United States, ethanol is produced by fermentation of cornstarch (23), which competes for the limited agricultural land needed for food and feed production (28), representing an obstacle to increasing ethanol utilization. In Brazil, ethanol is produced primarily from sugarcane juice, utilizing the yeast Saccharomyces cerevisiae for fermentation. Molasses, a residue of the sugar industry, is also used in Brazil for ethanol fermentation (31). Other sugars substrates, such as lactose from cheese whey $(1,9,14,21)$ and pentoses and hexoses from lignocellulosic biomass, can be converted to ethanol $(1,2,3,12$, $17,23,28,32$ ). The yeast $S$. cerevisiae and the bacterium Zymomonas mobilis are highly efficient in alcohol fermentation but they can not to use many source of sugars substrates (7). Therefore, there is great interest in construction of recombinant microorganisms which combine the efficient alcoholic fermentation observed in S. cerevisiae and Z. mobilis with the capacity to utilize a broad variety of sugar substrates (17). To this end, Escherichia coli KO11 (25) and Klebsiella oxytoca P2 (32) recombinants were constructed by integrating Z. mobilis genes pyruvate decarboxylase $(p d c)$ and alcohol dehydrogenase II (adhB) into their chromosomes.

The E. coli KO11 (KO11) and K. oxytoca P2 (P2) recombinants ferment sugar substrates that are not fermented by S. cerevisiae and Z. mobilis. The efficiency of KO11 and P2 in conversion of various substrates to ethanol, including simple sugars $(5,16,21,22,29)$, starch $(15)$, and hydrolyzed lignocellulose $(2,3,11,12,13)$ has been determined. In this study we examined growth and ethanol fermentation of sucrose, sugarcane juice and molasses by these recombinants.

\section{MATERIALS AND METHODS}

\section{Bacterial strains and media}

The recombinants E. coli KO11 (25) and K. oxytoca $\mathrm{P} 2$ (32), both containing $Z$. mobilis pyruvate decarboxylase $(p d c)$ and alcohol dehydrogenase II (adhB) genes were used. Stock cultures were maintained in LB broth with $40 \%$ glycerol. Chloramphenicol ( $40 \mu \mathrm{g} / \mathrm{mL})$ was added to all stock cultures, inoculum preparations and fermentation experiments.

Fermentation of sucrose was conducted in LB broth and minimal medium (MM) containing per liter: $2 \mathrm{~g}$ ammonium sulfate, $0.2 \mathrm{~g}$ magnesium sulfate, $0.7 \mathrm{~g}$ dibasic potassium phosphate, $0.3 \mathrm{~g}$ monosodium phosphate, $5 \mathrm{~mL}$ of a micronutrient solution (per liter: $5 \mathrm{~g}$ disodium EDTA, $0.22 \mathrm{~g}$ zinc sulfate. $7 \mathrm{H}_{2} \mathrm{O}, 0.5 \mathrm{~g}$ calcium chloride, $0.5 \mathrm{~g}$ ferrous sulfate $7 \mathrm{H}_{2} \mathrm{O}, 0.1 \mathrm{~g}$ ammonium molybdate. $4 \mathrm{H}_{2} \mathrm{O}, 0.16 \mathrm{~g}$ cupric chloride, $0.16 \mathrm{~g}$ cobalt chloride and $0.5 \mathrm{~g}$ manganese sulfate) and $1 \mathrm{~mL}$ thiamine solution (14). Thiamine stock solution $(0.1 \% \mathrm{w} / \mathrm{v})$ was filter sterilized.

Half-liter flasks containing minimal medium were autoclaved at $121^{\circ} \mathrm{C}$ for $20 \mathrm{~min}$. Sucrose (Merck) stock solution (40\% w/v) was sterilized at $121^{\circ} \mathrm{C}$ for $20 \mathrm{~min}$ and added to the media at final concentrations of $2 \%, 4 \%, 8 \%$ and $12 \%$ in a final volume of $200 \mathrm{~mL}$. One $\mathrm{mL}$ micronutrient solution, $200 \mu \mathrm{L}$ thiamine solution, $200 \mu \mathrm{L}$ chloramphenicol $(40 \mu \mathrm{g} / \mathrm{mL})$ and sucrose solutions were added to the media after cooling.

\section{Fermentation of sugarcane juice}

Sugarcane juice was centrifuged at $8.000 \mathrm{~g}$ for $8 \mathrm{~min}$. and 200 $\mathrm{mL}$ aliquots were autoclaved at $121^{\circ} \mathrm{C}$ for $15 \mathrm{~min}$ in $500-\mathrm{mL}$ fermentation flasks. Sugarcane juice was fermented under the following conditions: a) without supplements, $b$ ) with $0.5 \%$ yeast extract, c) with $0.5 \%$ yeast extract, micronutrients and thiamine, d) with LB broth compounds, e) with $0.2 \%$ ammonium sulfate, f) with $0.2 \%$ ammonium sulfate and micronutrients and g) with $0.2 \%$ ammonium sulfate, micronutrients and thiamine. Micronutrients, thiamine and chloramphenicol were added as previously described.

\section{Fermentation of sugarcane molasses}

Molasses was diluted 10-fold in distilled water or in vinasse. Two hundred $\mathrm{mL}$ were autoclaved at $121^{\circ} \mathrm{C}$ for $15 \mathrm{~min}$ in $500-\mathrm{mL}$ fermentation flasks and fermented under the following conditions: a) without supplementation, b) with $0.5 \%$ yeast extract and c) with LB broth reagents.

\section{Fermentation inoculum preparation}

Recombinant bacteria stored in LB broth/glycerol at $-20^{\circ} \mathrm{C}$ were transferred to LB agar containing $2 \%$ sucrose and incubated at $30^{\circ} \mathrm{C}$ for $24 \mathrm{~h}$. After growth, one well isolated colony was transferred from a plate to $10 \mathrm{~mL} \mathrm{LB}$ broth containing $2 \%$ sucrose, incubated overnight at $30^{\circ} \mathrm{C}$. This culture was added to $300 \mathrm{~mL}$ of LB broth containing $2 \%$ sucrose and once again incubated overnight at $30^{\circ} \mathrm{C}$ under agitation (100 rpm). After growth, optical density at 550nm (OD) of the cell culture was measured (Milton Roy model Spectronic 20 D spectrophotometer) to determine the volume needed to produce a fermentation medium $\mathrm{OD}$ of 1.0, equivalent to approximately 
$0.33 \mathrm{~g}$ dry weight of cells per liter $(25,32)$. This volume was centrifuged at $7000 \mathrm{~g}$ for $8 \mathrm{~min}$ and $4^{\circ} \mathrm{C}$ and the pellet transferred directly to the fermentation medium (4).

Fermentation experiments, sampling and analytical procedures

Fermentation was carried out in $\mathrm{pH}$-controlled reactors, as previously described (4). A pH/ORP controller (Cole-Parmer model 5656-00) was used to automatically maintain the minimal $\mathrm{pH}$ at 6.0 through addition of $2 \mathrm{M} \mathrm{KOH}$. Batch fermentation was carried out in duplicate and under continuous stirring at 100 rpm using a star-shaped magnetic stirrer (Variomag® Electronicrührer Multipoint HP stirrer). Fermentations were run at $30^{\circ} \mathrm{C}$ in a circulating water bath (Cole-Parmer Polystat Imersion Circulator).

Samples were removed for OD and ethanol determination throughout the $96 \mathrm{~h}$ incubation period. Samples for ethanol determination were centrifuged in microtubes at $11750 \mathrm{~g}$ and supernatants were stored at $-20^{\circ} \mathrm{C}$ for ethanol determination. The $\mathrm{pH}$ and amount of $2 \mathrm{M} \mathrm{KOH}$ used were recorded several times during the incubation for correction of the dilution that occurred during fermentation. Ethanol concentration was determined by gas chromatography using a Hewlett Packard Chromatograph (5890 series II plus), equipped with a HPWAX (Hewlett Packard) polyethylene glycol capillary column (25 m x $0.2 \mathrm{~mm} \times 0.2 \mathrm{~mm}$ ), flame ionization detector (FID) and electronic integrator (HP 3395 Integrator), using nitrogen as carrier gas. Ethanol concentration was determined by comparison with a calibration curve using propanol as internal standard. The following chromatograph conditions were used: $1 \mu \mathrm{L}$ sample injection volume; column temperature: 50 to $80^{\circ} \mathrm{C}\left(8^{\circ} \mathrm{C} / \mathrm{min}\right.$.); injector temperature: $200^{\circ} \mathrm{C}$; detector temperature: $250^{\circ} \mathrm{C}$. All tests were run in duplicate with two or more repetitions, and results are expressed as the average of all repetitions.

\section{Fermentation parameters}

The following definitions apply to this study: a) ethanol production: concentration of ethanol produced $(\mathrm{g} / \mathrm{L})$; b) volumetric productivity: ethanol produced per volume of medium per unit of time $(\mathrm{g} / \mathrm{L} / \mathrm{h})$ and $\mathrm{c})$ percent of maximum theoretical yield (\%): ethanol produced in relation to the maximum theoretical yield. This maximum theoretical yield of ethanol from sucrose was assumed to be $0.54 \mathrm{~g}$ ethanol/ $\mathrm{g}$ sugar (the other $0.46 \mathrm{~g}$ being converted to $\mathrm{CO}_{2}$ ). Maximum theoretical yields were calculated in relation to the amount of sugar present at the beginning of the fermentations, with no corrections made for unconsumed sugar.

\section{RESULTS}

\section{Fermentation of sucrose in minimal medium}

Escherichia coli KO11 presented maximum growth in MM after about $36 \mathrm{~h}$, reaching $0.8 \mathrm{~g}$ cells/L (OD 2.4) at $2 \%$ sucrose and $1.1 \mathrm{~g} / \mathrm{L}(\mathrm{OD}$ 3.2) in MM at a sucrose concentration of $4 \%$ or more (Fig. 1A). Klebsiella oxytoca $\mathrm{P} 2$ presented maximum growth after about $24 \mathrm{~h}$, reaching an OD of 2.0-2.5, at $2 \%$ to $4 \%$ sucrose, and OD of 4.0 at $8 \%$ to $12 \%$ sucrose (Fig. 1C). Flocculation of K. oxytoca P2 in medium containing sucrose interfered with OD determination and OD values reported in Fig. 1C therefore do not accurately represent the cell mass produced by $\mathrm{P} 2$.

Ethanol production by E. coli KO11 and K. oxytoca $\mathrm{P} 2$ in MM using sucrose as carbon source is presented in Figs. 1B and 1D. Ethanol production, percent of maximum theoretical yield and volumetric productivity by both recombinants are listed in Table 1. Strain E. coli KO11 produced more ethanol than $K$. oxytoca P2 in MM, except at $12 \%$ sucrose. Ethanol production in medium with $2 \%$ sucrose was $75 \%$ of the maximum theoretical yield for $\mathrm{KO} 11$ and $55 \%$ for $\mathrm{P} 2$. Recombinant KO11 presented 41\% (26.6 g ethanol/L) of the maximum theoretical yield while P2 presented $47 \%$ (30.9 g ethanol/L) at a $12 \%$ sucrose concentration (Figs. $1 \mathrm{~B}$ and D and Table 1). The carbon source was probably the limiting factor for ethanol production at $2 \%$ to $4 \%$ sucrose while other nutrients were limiting at $8 \%$ to $12 \%$ sucrose. Ethanol production could probably increase at these higher sugar concentrations if the incubation time were increased, resulting in greater ethanol production efficiency. Recombinant P2 presented a lower yield but a higher volumetric productivity than KO11 (Table 1), converting sugar to ethanol more rapidly at all sugar concentrations tested.

The $\mathrm{pH}$ of growth medium with $2 \%$ - $4 \%$ sucrose increased after $60-72 \mathrm{~h}$ incubation of KO11 while an increase in growth medium $\mathrm{pH}$ occurred after $36 \mathrm{~h}$ at $2 \%$ - $4 \%$ sucrose, and after $48 \mathrm{~h}$ at $8 \%$ sucrose for strain $\mathrm{P} 2$.

Table 1. Ethanol production (g/L), Maximum theoretical yield a $(\%)$, and Volumetric productivity $(\mathrm{g} / \mathrm{L} / \mathrm{h})^{\text {b }}$ by Escherichia coli strain KO11 and Klebsiella oxytoca strain P2 in minimal medium added of sucrose.

\begin{tabular}{|c|c|c|c|c|c|c|c|c|}
\hline & \multicolumn{8}{|c|}{ Sucrose added to minimal medium } \\
\hline & \multicolumn{2}{|c|}{$2 \%$} & \multicolumn{2}{|c|}{$4 \%$} & \multicolumn{2}{|c|}{$8 \%$} & \multicolumn{2}{|c|}{$12 \%$} \\
\hline & KO11 & $\mathrm{P} 2$ & KO11 & $\mathrm{P} 2$ & KO11 & $\mathrm{P} 2$ & KO11 & $\mathrm{P} 2$ \\
\hline $\begin{array}{l}\text { Ethanol } \\
\text { production }\end{array}$ & 7.7 & 5.9 & 15.8 & 11.3 & 25.9 & 21.3 & 26.6 & 30.9 \\
\hline $\begin{array}{l}\text { Maximum } \\
\text { theoretical yield } \\
\text { Volumetric }\end{array}$ & 75 & 55 & 70 & 52 & 60 & 49 & 41 & 47 \\
\hline productivity & 0.23 & 0.3 & 0.41 & 0.47 & 0.43 & 0.64 & 0.37 & 0.66 \\
\hline
\end{tabular}




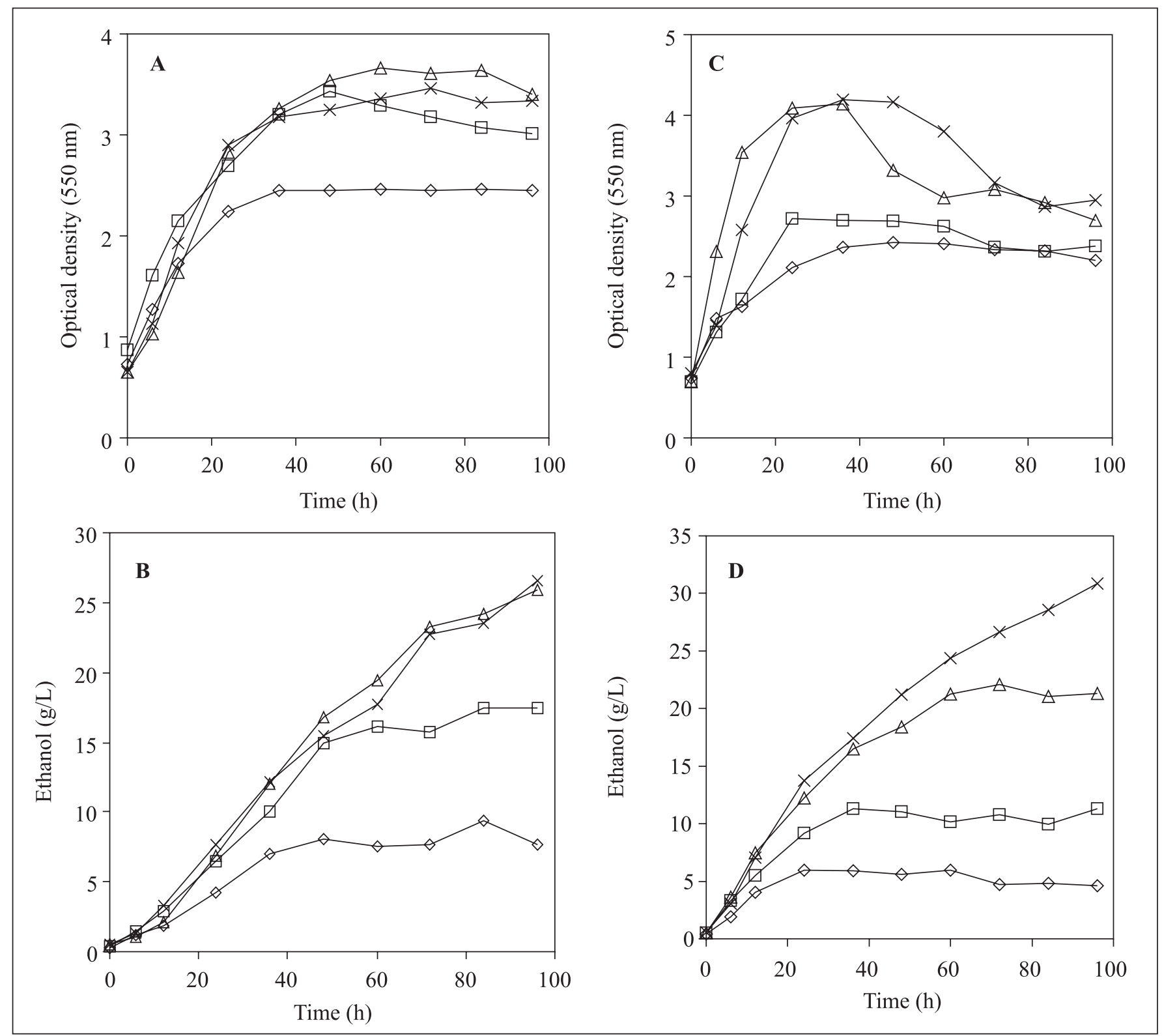

Figure 1. Growth and ethanol production by Escherichia coli KO11 (A and B) and Klebsiella oxytoca P2 (C and D) in minimal medium containing sucrose in the concentrations $(\mathrm{w} / \mathrm{v})$ of $2 \%(\diamond), 4 \%(\square), 8 \%(\triangle)$ and $12 \%(\times)$.

\section{Fermentation of sucrose in LB broth}

Growth and Ethanol production is presented in Fig. 2, while Table 2 summarizes ethanol production, percent of maximum theoretical yield, and volumetric productivity for KO11 and P2. Recombinant KO11 (Fig. 2A) grew slightly more slowly than $K$. oxytoca $\mathrm{P} 2$ (Fig. 2C). KO11 cell mass reached about $1.7 \mathrm{~g} / \mathrm{L}$ (OD $5.0)$ at a $2 \%$ sucrose concentration and about $2.0 \mathrm{~g} / \mathrm{L}(\mathrm{OD} 6.0)$ at higher sucrose concentrations after $24 \mathrm{~h}$. K. oxytoca $\mathrm{P} 2$ presented an OD of 5.0 at $2 \%$ sucrose and 7.0 at $12 \%$ sucrose after $24 \mathrm{~h}$ incubation (Fig 2C).
Ethanol production was similar for both recombinants at $2 \%$ to $4 \%$ sucrose, corresponding to about $94-95 \%$ of the maximum theoretical yield. Both recombinants produced 20.3 $\mathrm{g}$ ethanol/L at $4 \%$ sucrose. Nevertheless, KO11 presented higher ethanol production at $8 \%$ to $12 \%$ sucrose. While KO11 presented about $96 \%$ efficiency $(41.3 \mathrm{~g}$ ethanol/L) in LB containing $8 \%$ sucrose, $\mathrm{P} 2$ presented only about $73 \%$ efficiency (31.4g ethanol/L). At a $12 \%$ sucrose concentration, KO11 presented $68.7 \%$ efficiency $(44.5 \mathrm{~g}$ ethanol/L) and $\mathrm{P} 2$ presented $57.9 \%$ efficiency (37.5g ethanol/L). K. oxytoca $\mathrm{P} 2$ converted 

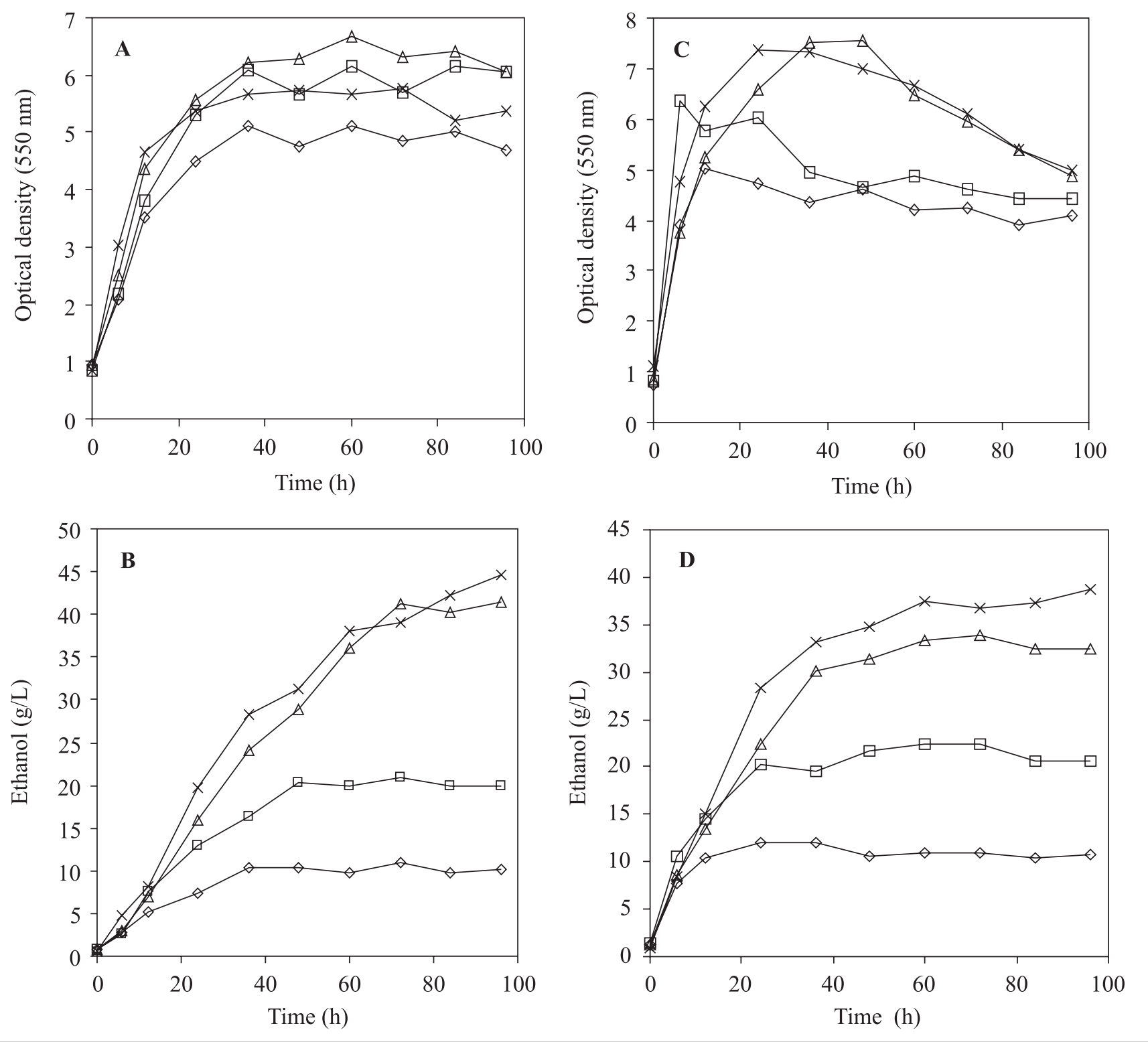

Figure 2. Growth and ethanol production by Escherichia coli KO11 (A and B) and Klebsiella oxytoca P2 (C and D) in LB broth containing sucrose in the concentrations (w/v) of $2 \%(\diamond), 4 \%(\square), 8 \%(\triangle)$ and $12 \%(\times)$.

sucrose to ethanol faster than E. coli KO11, and presented higher volumetric productivity. Increase in medium $\mathrm{pH}$ occurred after $48-60 \mathrm{~h}$ of fermentation by KO11 and after only $12-36 \mathrm{~h}$ fermentation by strain P2.

Fermentation of sugarcane juice without supplementation, supplemented with yeast extract and with yeast extract, thiamine and micronutrients

Fig. 3 presents growth and ethanol production by E. coli KO11 and K. oxytoca $\mathrm{P} 2$ under these conditions. Although KO11 and $\mathrm{P} 2$ did not grow in sugarcane juice without supplements (Fig. 3A), ethanol yield was approximately $11 \mathrm{~g} / \mathrm{L}$ after $96 \mathrm{~h}$ (Fig. 3B). Both bacteria presented rapid growth and ethanol production when supplements were added. In sugarcane juice with $0.5 \%$ yeast extract, ethanol production was approximately $34 \mathrm{~g} / \mathrm{L}$ for both bacteria after $96 \mathrm{~h}$. Upon addition of yeast extract, thiamine and micronutrients, KO11 ethanol production rose to $39.4 \mathrm{~g}$ ethanol/L and $\mathrm{P} 2$ production to $42.1 \mathrm{~g} / \mathrm{L}$ after $96 \mathrm{~h}$ (Fig. 3B). Ethanol production in this case was slightly higher than in sugarcane juice with only yeast extract added. 
Table 2. Ethanol production (g/L), Maximum theoretical yield ${ }^{\mathrm{a}}(\%)$, and Volumetric productivity $(\mathrm{g} / \mathrm{L} / \mathrm{h}){ }^{\mathrm{b}}$ by Escherichia coli strain KO11 and Klebsiella oxytoca strain P2 in LB broth added of sucrose.

\begin{tabular}{lllllllllll}
\hline & \multicolumn{6}{c}{ Sucrose added to LB broth } \\
\cline { 2 - 9 } & \multicolumn{3}{c}{$2 \%$} & \multicolumn{2}{c}{$4 \%$} & \multicolumn{2}{c}{$8 \%$} & \multicolumn{2}{c}{$12 \%$} \\
\cline { 2 - 9 } & KO11 & P2 & KO11 & P2 & KO11 & P2 & KO11 & P2 \\
\hline $\begin{array}{l}\text { Ethanol } \\
\text { production }\end{array}$ & 10.2 & 10.3 & 20.3 & 20.3 & 41.3 & 31.4 & 44.5 & 37.5 \\
$\begin{array}{l}\text { Maximum } \\
\text { theoretical yield }\end{array}$ & 94.4 & 95.4 & 94 & 94 & 95.6 & 72.7 & 68.7 & 57.9 \\
$\begin{array}{l}\text { Volumetric } \\
\text { productivity }\end{array}$ & 0.41 & 1.08 & 0.81 & 1.52 & 0.75 & 1.21 & 0.96 & 1.4 \\
\hline
\end{tabular}

${ }^{a}$ Maximum theoretical yield of ethanol from sucrose is considered $0.54 \mathrm{~g}$ ethanol/g sucrose (more $0.46 \mathrm{~g}$ carbon dioxide/g sucrose); ${ }^{\mathrm{b}}$ Calculated from the early stages of fermentation.

\section{Fermentation of sugarcane juice supplemented with LB broth reagents}

Fig. 4 shows growth and ethanol production by KO11 and by $\mathrm{P} 2$ in sugarcane juice supplemented with LB broth components. E. coli KO11 produced $18.5 \mathrm{~g}$ of ethanol/L after $24 \mathrm{~h}$, with strong inhibition of fermentation after this time, reaching only $23 \mathrm{~g}$ ethanol/L after $96 \mathrm{~h}$ (Fig. 4B), a much lower value than obtained from sugarcane juice with $0.5 \%$ yeast extract (34 g/L, Fig. 3B). To test the effect of $\mathrm{NaCl}$ on growth and ethanol production, KO11 was grown in sugarcane juice supplemented with $\mathrm{LB}$ broth reagents without $\mathrm{NaCl}$. Growth and ethanol production were slightly higher, with ethanol production reaching about $30 \mathrm{~g}$ of ethanol/L within $96 \mathrm{~h}, 7 \mathrm{~g} / \mathrm{L}$ higher than when grown in medium with all LB components added. In this medium, P2 presented higher alcoholic production (Fig. 4B), reaching $44.2 \mathrm{~g}$ ethanol/L after $96 \mathrm{~h}$. This value is approximately twice that of the ethanol produced by KO11 under the same conditions.

Fermentation of sugarcane juice supplemented with ammonium sulfate, with ammonium sulfate and micronutrients and with ammonium sulfate, micronutrients and thiamine

E. coli $\mathrm{KO} 11$ and $K$. oxytoca $\mathrm{P} 2$ presented little growth in sugarcane juice with ammonium sulfate (Fig. 5A). Ethanol production (Fig. 5B) was greater than the $11 \mathrm{~g} / \mathrm{L}$ produced in sugarcane juice alone (Fig. 3B). Likewise, addition of micronutrients and thiamine did not result in increased ethanol production by KO11. In all cases KO11 produced only about $25 \mathrm{~g}$ ethanol/L after $96 \mathrm{~h}$ (Fig. 5B).

K. oxytoca $\mathrm{P} 2$ presented better fermentation than $\mathrm{KO} 11$ in sugarcane juice supplemented with ammonium sulfate. P2 ethanol production after $96 \mathrm{~h}$ was similar when fermenting sugarcane juice supplemented with ammonium sulfate $(30.2 \mathrm{~g} /$ L) or with ammonium sulfate and micronutrients $(31.6 \mathrm{~g} / \mathrm{L})$. However, when thiamine was also added, ethanol production by P2 increased to $37.5 \mathrm{~g}$ ethanol/L. This value is higher than

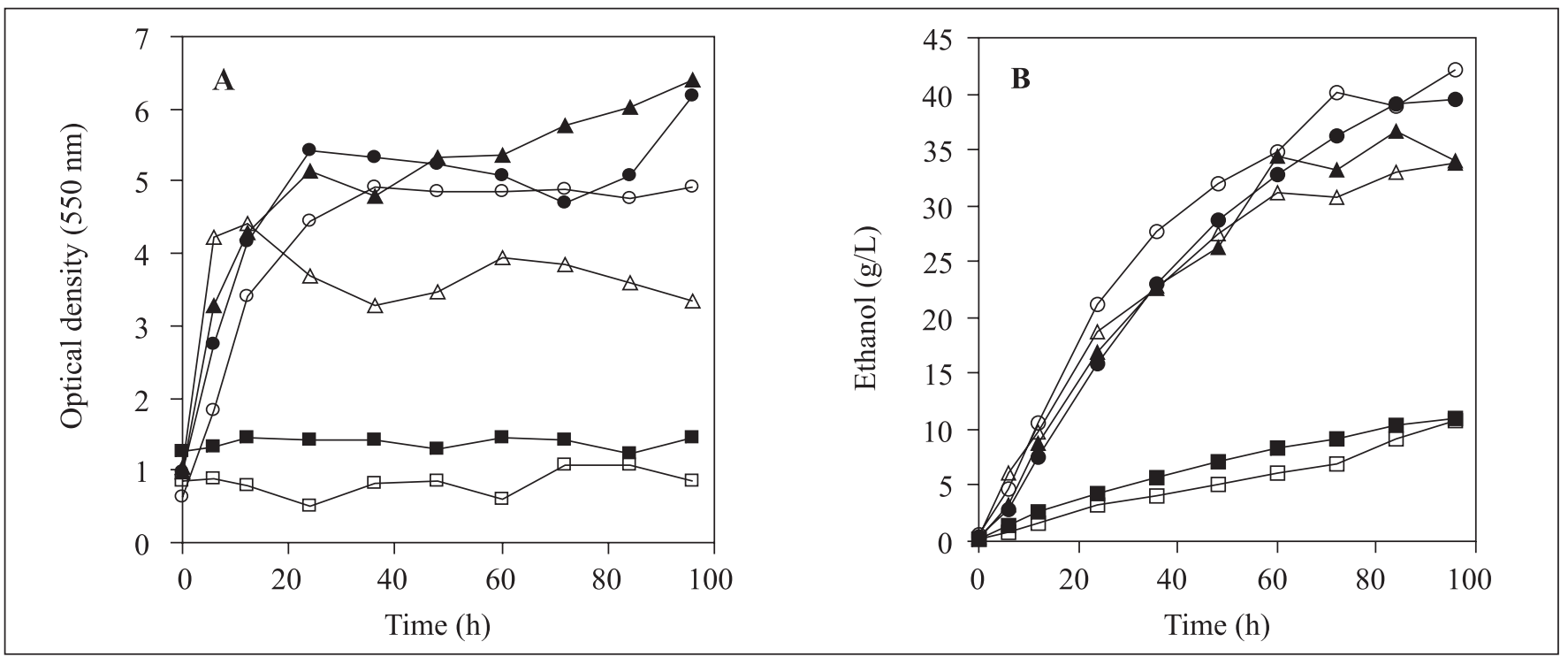

Figure 3. Growth (A) and ethanol production (B) by Escherichia coli strain KO11 (closed symbols) and Klebsiella oxytoca strain P2 (opened symbols) during sugarcane juice fermentation. $[\boldsymbol{\square}]$ Without supplementation; $[\boldsymbol{\Delta} \triangle$ ] supplemented with $0.5 \%$ yeast extract; $[\bullet \bigcirc]$ supplemented with $0.5 \%$ yeast extract, thiamine and micronutrients. 
that obtained in sugarcane juice supplemented with yeast extract (34 g/L, Fig. 3B), but is lower than obtained with addition of yeast extract, micronutrients and thiamine (42.1 g/L, Fig. 3B) or LB components (44.2 g/L, Fig. 4B). These results indicate that thiamine addition improves alcoholic yield by $\mathrm{P} 2$, an effect not observed for KO11.

\section{Fermentation of sugarcane molasses}

Results of KO11 and P2 fermentation of molasses diluted 10-fold in distilled water and in vinasse are presented in Fig. 6A and $6 \mathrm{~B}$, respectively. E. coli KO11 molasses fermentation diluted in water or in vinasse resulted in low ethanol yields. Suplementation of molasses did not result in an increase in

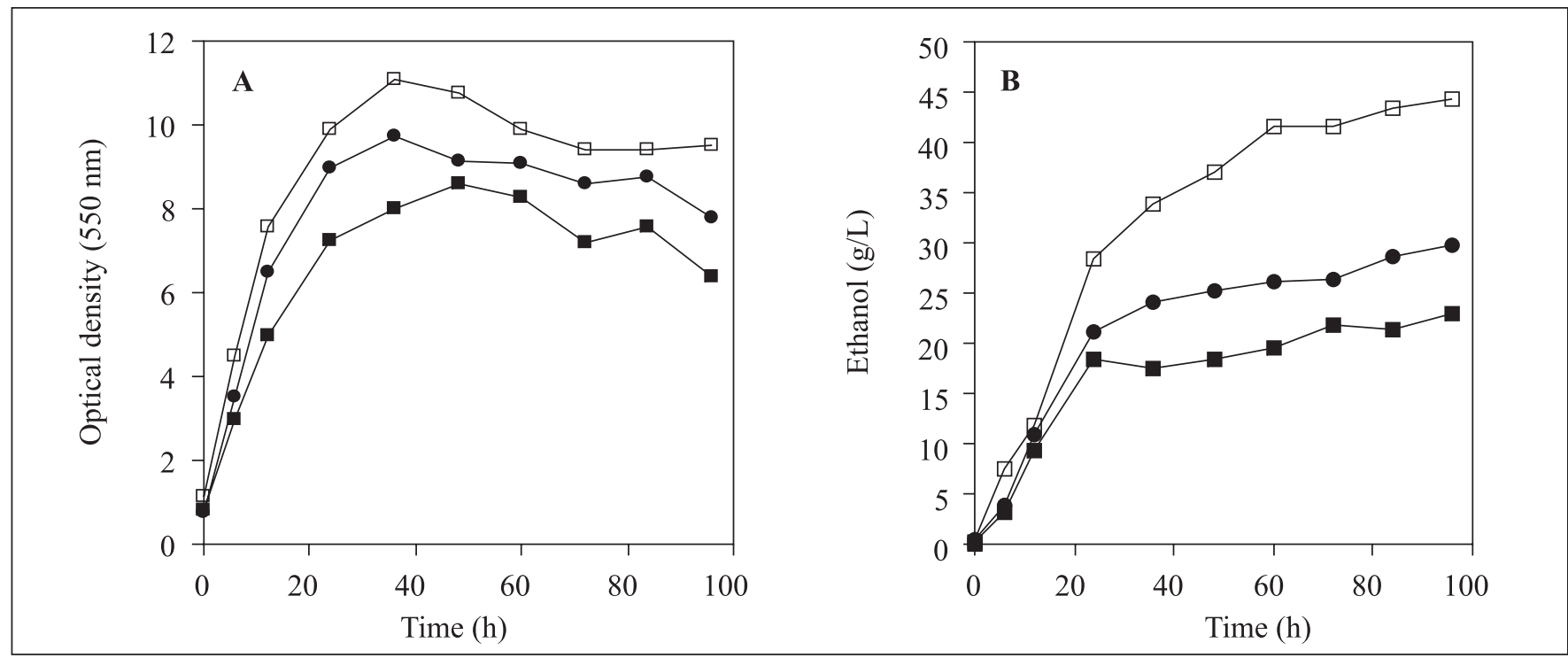

Figure 4. Growth (A) and ethanol production (B) by Escherichia coli strain KO11 (closed symbols) and Klebsiella oxytoca strain P2 (opened symbols) during sugarcane juice fermentation. [ $\square$ ] Supplemented with LB broth reagents; [0] supplemented with $\mathrm{LB}$ broth reagents without $\mathrm{NaCl}$.
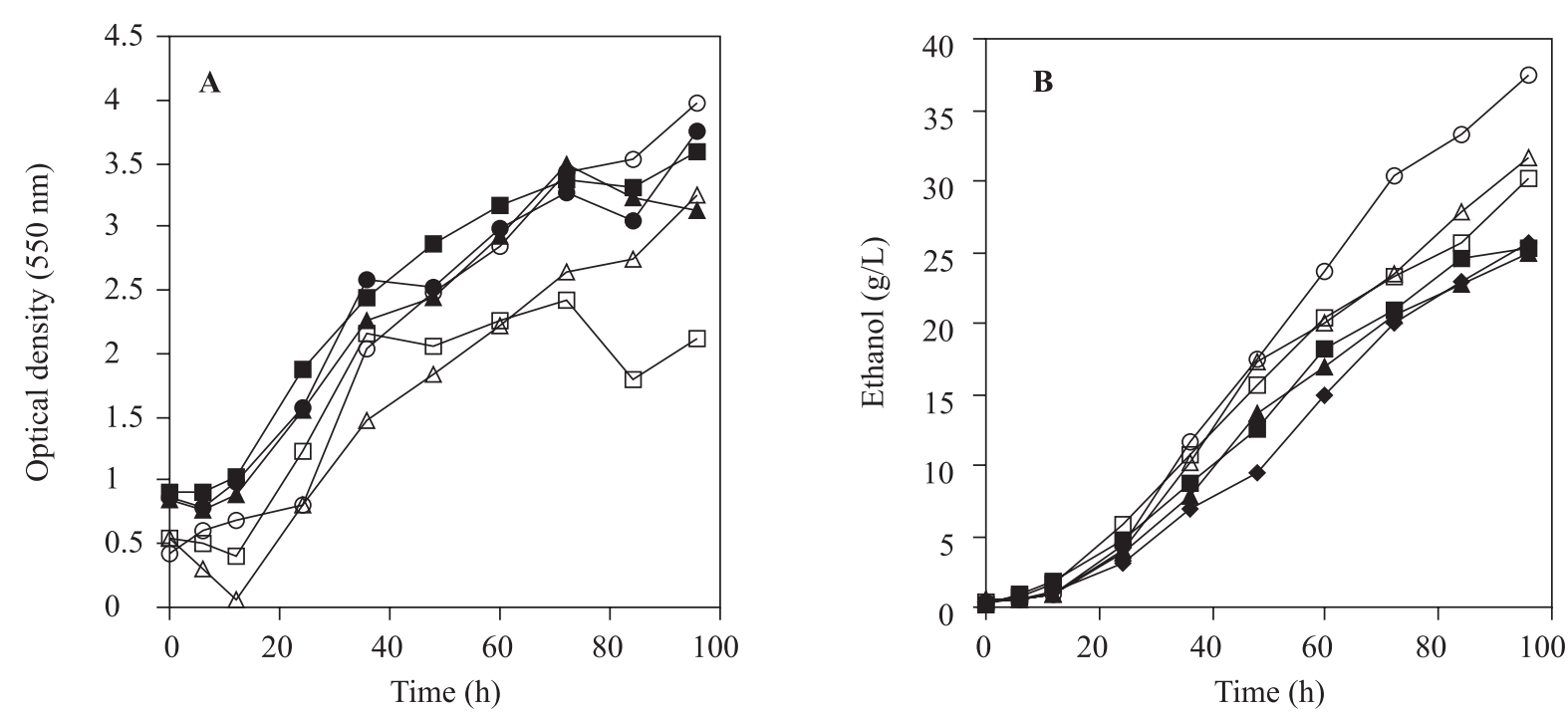

Figure 5. Growth (A) and ethanol production (B) by Escherichia coli strain KO11 (closed symbols) and Klebsiella oxytoca strain P2 (opened symbols) during sugarcane juice fermentation. [ $\square$ ] Supplemented with $0.2 \%$ ammonium sulfate; [ $\Delta \triangle$ ] supplemented with $0.2 \%$ ammonium sulfate and micronutrients; [ $\bigcirc$ ] supplemented with $0.2 \%$ ammonium sulfate, micronutrients and thiamine. 
ethanol production by KO11, that produced only $18.1 \mathrm{~g}$ ethanol/ $\mathrm{L}$ whithout suplementation and about $15.5 \mathrm{~g} / \mathrm{L}$ with yeast extract or LB reagents. In molasses diluted in vinasse, $\mathrm{KO} 11$ produced $14.4 \mathrm{~g}$ ethanol/L without supplements and about $16.6 \mathrm{~g} / \mathrm{L}$ with yeast extract or with LB components. There was a relatively $\mathrm{KOH}$ consumption during fermentation to maintain $\mathrm{pH}$. Acid analysis by HPLC indicated high lactic acid concentration in the fermentation medium (results not shown), indicating a possible loss of ethanologenicity by KO11.

In contrast to KO11, K. oxytoca $\mathrm{P} 2$ fermented molasses efficiently. In molasses diluted in water, ethanol production after $96 \mathrm{~h}$ was $25.6 \mathrm{~g} / \mathrm{L}$ (no supplements), $24.6 \mathrm{~g} / \mathrm{L}$ (with yeast extract) and $27.8 \mathrm{~g} / \mathrm{L}$ (with LB). In molasses diluted in vinasse, ethanol production was $24.4 \mathrm{~g} / \mathrm{L}$ (no supplements), $24.6 \mathrm{~g} / \mathrm{L}$ (with yeast extract) and $25.1 \mathrm{~g} / \mathrm{L}$ (with LB). Addition of yeast extract or LB promoted rapid $\mathrm{P} 2$ fermentation that reached a maximum ethanol yield within $24 \mathrm{~h}$ and stabilized after this time probably because of sugar depletion in the medium.

\section{DISCUSSION}

For sucrose fermentation, Escherichia coli KO11 generally presented better fermentation results if only ethanol produced is considered. However, if one considers volumetric productivity, $\mathrm{P} 2$ presented better results than KO11. Rapid ethanol production by $\mathrm{P} 2$ was also reported by others authors (12), who concluded that $\mathrm{P} 2$ presents dominance in the earlier part of the fermentation in co-culture with other organisms. A probable explanation for lower ethanol yield from P2 in relation to KO11 when sugar is a limiting factor, is its higher cell mass production and diversion of part of the sugar to capsule polysaccharides production. This can be observed by comparing the $8 \%$ sucrose curves in Figs. 2B and 2D. K. oxytoca $\mathrm{P} 2$ growth stabilized in ethanol after 36h, while E. coli KO11 presented the same result after only $72 \mathrm{~h}$. In both cases, the curves indicate sugar depletion in the medium, since KO11 produced nearly the maximum theoretical yield (96\%) and $\mathrm{P} 2$ presented $73 \%$, with the remaining sugar probably having been utilized for capsule production.

The $K$. oxytoca $\mathrm{P} 2$ culture flocculated in medium containing sucrose. Flocculation presents some advantages for alcohol production, facilitating separation of cells and eliminating the need for centrifugation for cell recovery in an industrial setting (27). Flocculation is also a way to maintain high cell density in a continuous-flow bioreactor. It was observed that flocculation in Z. mobilis is influenced by the ethanol concentration in the medium (27). The influence of ethanol concentration on $K$. oxytoca P2 flocculation was not investigated. This flocculation might explain the progressive decline in OD observed.

According to Beall et al. (4), the rise in medium $\mathrm{pH}$ provides a convenient marker for completion of fermentation and appears to coincide with maximum ethanol concentration. Increase in medium $\mathrm{pH}$ occurs due to catabolism of complex nutrients, which releases ammonia after sugar depletion (4). The rapid increase in medium $\mathrm{pH}$ observed for recombinant P2 confirms the greater ethanol production efficiency of this strain as compared to KO11. Complex nutrients are absent in $\mathrm{MM}$ and the rise in $\mathrm{pH}$ observed in this medium may be explained by cell lysis and release organic macromolecules that can be utilized by growing cells.
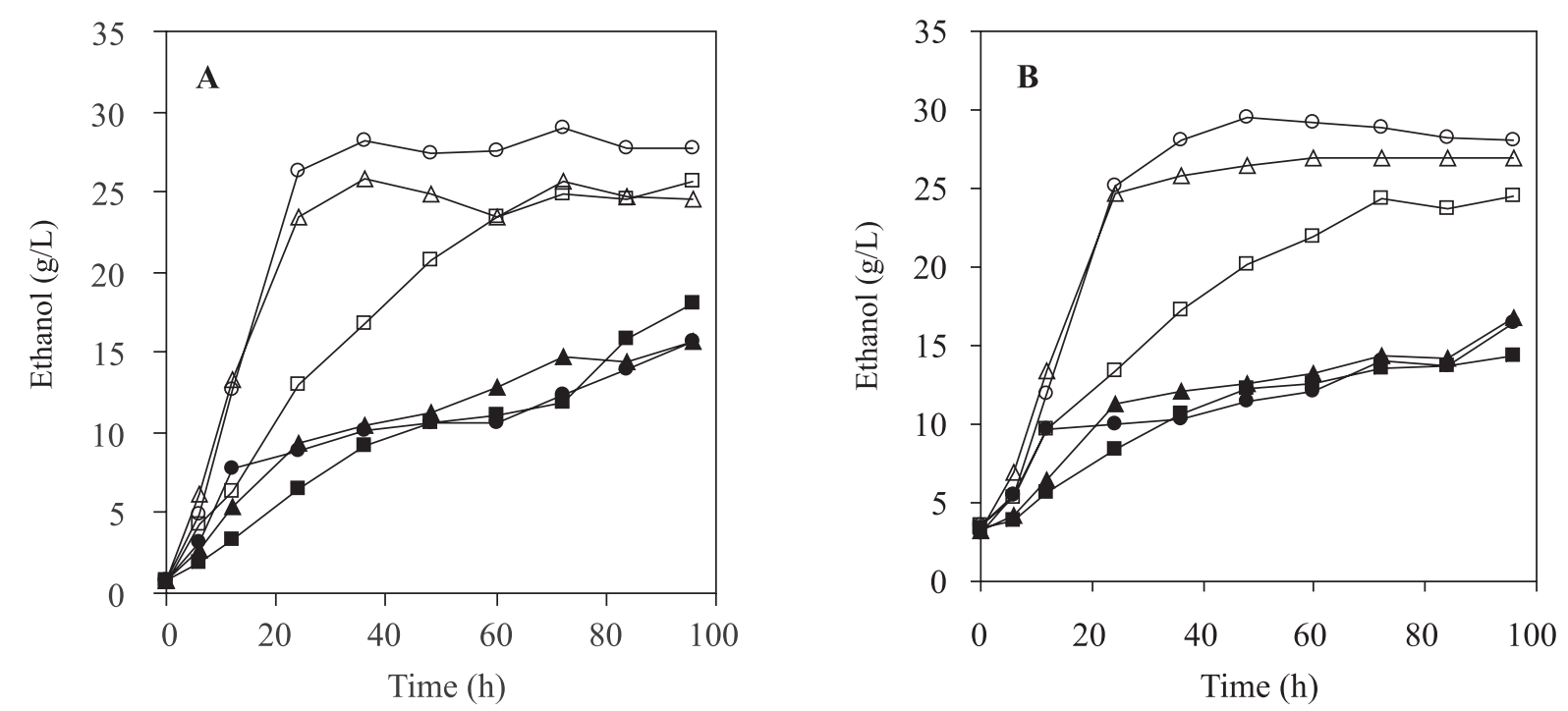

Figure 6. Ethanol production by Escherichia coli strain KO11 (closed symbols) and Klebsiella oxytoca strain P2 (opened symbols) during sugarcane molasses fermentation diluted 10X in distillated water (A) or diluted 10X in vinasse (B). [ $\square \square$ ] Without supplementation; [ $\triangle \triangle$ ] supplemented with $0.5 \%$ yeast extract; [ $\bigcirc$ ] supplemented with LB broth reagents. 
The results obtained in this work for KO11 are similar to those observed in a previous study (24), in which greater than $90 \%$ of the maximum theoretical yield was reached upon fermentation of 9\% sucrose. However, P2 presented poorer results than in that study, producing $73 \%$ of the maximum theoretical yield with $8 \%$ sucrose and $58 \%$ with $12 \%$ sucrose.

Growth and fermentation of sugarcane juice to ethanol by $\mathrm{KO} 11$ and $\mathrm{P} 2$ required addition of nutrients. For instance, $0.5 \%$ yeast extract was sufficient for rapid growth of both recombinants, but addition of yeast extract, micronutrients and thiamine promoted better ethanol production. The low KO11 ethanol yield in sugarcane juice containing LB broth ( $23 \mathrm{~g} / \mathrm{L})$, as compared to the yield in sugarcane juice with $0.5 \%$ yeast extract $(34 \mathrm{~g} / \mathrm{L})$ was unexpected. When $\mathrm{NaCl}$ was omitted from the medium, KO11 ethanol production increased to $30 \mathrm{~g}$ of ethanol/ $\mathrm{L}$ after $96 \mathrm{~h}$. Previous studies reported reduction in the fermentation rate of $E$. coli $\mathrm{pLOI} 297$, the recombinant strain that gave rise to $\mathrm{KO} 11$, when more than $200 \mathrm{mM}$ of $\mathrm{NaCl}$ was added to the medium (4). Similarly, a decrease in sugarcane juice fermentation by $Z$. mobilis was described at $\mathrm{NaCl}$ concentrations greater than $7 \mathrm{~g} / \mathrm{L}$, and a reduction in biomass production from 2.8 to $0.9 \mathrm{~g} / \mathrm{L}$ was observed when the salt concentration increased from 3 to $9 \mathrm{~g} \mathrm{NaCl} / \mathrm{L}$ (18). These results suggest that high osmolarity of the medium could be responsible for the reduction in alcoholic fermentation of the sugarcane juice supplemented with LB components. These results are in agreement with those of Underwood et al. (30), who also observed that high growth medium osmolarity reduced KO11 growth and volumetric production. In contrast to KO11, P2 presented the best fermentation result in sugarcane juice supplemented with LB (44.2 $\mathrm{g}$ ethanol/L after $96 \mathrm{~h}$ ), producing more than twice the concentration KO11 under the same conditions. Thus, P2 was not affected by the high osmolarity of the medium.

Addition of $0.2 \%$ ammonium sulfate to sugarcane juice resulted in growth and ethanolic fermentation by both recombinants. Nevertheless, micronutrient and thiamine supplements did not improve KO11 ethanol production, with only $25 \mathrm{~g}$ ethanol/L produced, only higher than in fermentation of sugarcane juice supplemented with LB. P2 also presented better ethanol production in sugarcane juice supplemented with inorganic nutrients. Although micronutrients and thiamine did not improve KO11 ethanol production, addition of these nutrients resulted in higher ethanol production by P2. Addition of thiamine alone increased $\mathrm{P} 2$ ethanol production, but had no effect on fermentation by KO11.

Molasses and vinasse are byproducts of the sugar-alcohol industry in Brazil. Molasses is used as additive in ethanol production due to its high sugar content while vinasse is used for irrigation due to its high micronutrient content. The ethanol concentration in vinasse is relatively high (about $3.5 \mathrm{~g} / \mathrm{L}$ ) since it is a residue of the alcohol industry and is obtained in the final distillation process. E. coli KO11 fermented molasses with low efficiency under all conditions of dilution and supplementation. The high amount of $\mathrm{KOH}$ used to maintain the $\mathrm{pH}$ during fermentation can be related to loss of ethanologenicity by KO11. Previous studies describe high KO11 instability during continuous fermentation, with rapid ethanologenicity loss $(19,20)$. The poorer results obtained in this work with sugarcane juice containing LB and with molasses may be due to the instability of the Pet operon described. Unlike KO11, K. oxytoca P2 fermented molasses with high efficiency. The recombinant $K$. oxytoca $\mathrm{P} 2$ presented better results than $E$. coli KO11 in fermentation of sugarcane juice and molasses, producing more ethanol and presenting higher volumetric production and higher stability during fermentation.

\section{ACKNOWLEDGMENTS}

This work was supported by governamental agencies: Financiadora de Estudos e Projetos (FINEP) and Conselho Nacional de Desenvolvimento Científico e Tecnológico (CNPq), Brazil. The autors are grateful to Ann Honor Mounteer for the English translation of this paper.

\section{RESUMO}

\section{Fermentação etanólica de sacarose, caldo de cana-de- açúcar e de melaço por Escherichia coli KO11 e Klebsiella oxytoca $\mathbf{P 2}$}

As bactérias recombinantes Escherichia coli KO11 e Klebsiella oxytoca $\mathrm{P} 2$ fermentaram sacarose a etanol. Em meio mínimo com $2 \%$ ou $12 \%$ de sacarose, KO11 apresentou, respectivamente, $75 \%$ e $41 \%$ do rendimento máximo teórico $(0,54 \mathrm{~g}$ de etanol/g de sacarose). No caldo Luria-Bertani (LB) com até $8 \%$ de sacarose, KO11 apresentou rendimento de aproximadamente $94-96 \%$ e com $12 \%$ de sacarose, KO11 apresentou cerca de $69 \%$ de rendimento $(44,5 \mathrm{~g}$ de etanol/L). A porcentagem do rendimento máximo teórico obtida com P2 em meio mínimo com $2 \%$ de sacarose foi de $55 \%$ e com $12 \%$ de sacarose foi de $47 \%$. Em LB com 2 ou $4 \%$ de sacarose, $\mathrm{P} 2$ apresentou 94-95\% do rendimento máximo teórico, porém somente cerca de $73 \%$ com $8 \%$ de sacarose $(31,4 \mathrm{~g}$ de etanol $/ \mathrm{L})$ e $58 \%$ com $12 \%$ de sacarose $(37,5 \mathrm{~g} / \mathrm{L})$. A produtividade volumétrica em $\mathrm{LB}$ contendo $2 \%$ de sacarose foi de $0,41 \mathrm{~g} / \mathrm{L} / \mathrm{h}$ para $\mathrm{KO} 11$ e de $1,1 \mathrm{~g} / \mathrm{L} / \mathrm{h}$ para $\mathrm{P} 2$, enquanto que em $\mathrm{LB}$ com $12 \%$ de sacarose, a produtividade foi $0,96 \mathrm{~g} / \mathrm{L} / \mathrm{h}($ KO11) e $1,4 \mathrm{~g} / \mathrm{L} / \mathrm{h}$ (P2). Durante a fermentação do caldo de cana, E. coli KO11 e K. oxytoca $\mathrm{P} 2$ produziram, respectivamente, $39,4 \mathrm{~g}$ de etanol/L e $42,1 \mathrm{~g} / \mathrm{L}$ quando suplementado com $0,5 \%$ de extrato de levedura, micronutrientes e tiamina. No caldo de cana suplementado com os reagentes do meio LB, KO11 apresentou forte inibição da fermentação alcoólica, produzindo apenas $23,0 \mathrm{~g}$ de etanol/L, enquanto que $\mathrm{P} 2$ produziu $44,2 \mathrm{~g} / \mathrm{L}$. A produção de etanol por $\mathrm{KO} 11$ e P2, no caldo de cana suplementado com a) $0,2 \%$ de sulfato 
de amônio foi, respectivamente: 25,3 e 30,2 g/L, b) com sulfato de amônio e micronutrientes: 24,9e $31,6 \mathrm{~g} / \mathrm{L}, \mathrm{c}$ ) com sulfato de amônio, micronutrientes e tiamina: 25,6 e 37,5 g/L. Durante a fermentação do melaço, E. coli KO11 apresentou baixa produção de etanol e alta produção de ácido láctico. $K$. oxytoca $\mathrm{P} 2$ produziu $25 \mathrm{~g}$ de etanol/L a partir de melaço diluído $10 \mathrm{X}$ em água, com ou sem adição de $0,5 \%$ de extrato de levedura e $27,8 \mathrm{~g} / \mathrm{L}$ com reagentes do caldo LB após 96h. P2 produziu 24,5, 26,9, e 28,0 g de etanol/ Lem melaço diluído $10 \mathrm{X}$ em vinhoto, vinhoto com $0,5 \%$ de extrato de levedura e com os reagentes do caldo LB, respectivamente.

Palavras-chave: Escherichia coli KO11, Klebsiella oxytoca P2, Zymomonas mobilis, fermentação da sacarose, fermentação etanólica

\section{REFERENCES}

1. Alterthum, F.; Ingram, L.O. Efficient ethanol production from glucose, lactose, and xylose by recombinant Escherichia coli. Appl. Environ. Microbiol., 55, 1943-1948, 1989.

2. Asghari, A.; Bothast, R.J.; Doram, J.B.; Ingram, L.O. Ethanol production from hemicellulose hydrolysates of agricultural residues using genetically engineered Escherichia coli strain KO11. J. Indust. Microbiol., 16, 42-47, 1996.

3. Beall, D.S.; Ingram, L.O. Genetic engineering of soft-rot bacteria for ethanol production from lignocellulose. J. Indust. Microbiol., 11, 151-155, 1993.

4. Beall, D.S.; Ohta, K.; Ingram, L.O. Parametric studies of ethanol production from xylose and other sugars by recombinant Escherichia coli. Biotechnol. Bioeng., 38, 296-303, 1991.

5. Bothast, R.J.; Saha, B.C.; Vance Flosenzier, A.; Ingram, L.O. Fermentation of L-arabinose, D-xylose and D-glucose by ethanologenic recombinant Klebsiella oxytoca strain P2. Biotechnol. Lett., 16, 401406, 1994.

6. BRASIL. Ministério da Indústria e do Comércio. Secretaria de Tecnologia Industrial. Estado-da-arte da produção de etanol a partir da madeira; coletânea/Tecnologia da produção de etanol a partir de materiais celulósicos. v.1. Brasília, DF. 190p., 1981.

7. Bräu, B.; Sahm, H. Cloning and expression of the structural gene for pyruvate decarboxylase of Zymomonas mobilis in Escherichia coli. Arch. Microbiol., 144, 296-301, 1986.

8. Campbell, C.J.; Laherrère, J.H. The end of cheap oil. Sci. Am., 3, 78-83, 1998.

9. Carey, V.C.; Walia, S.K.; Ingram, L.O. Expression of lactose transposon (Tn951) in Zymomonas mobilis. Appl. Environ. Microbiol., 46, 1163-1168, 1983.

10. Carta da Anfavea. São Paulo: Associação Nacional dos Fabricantes de Veículos Automotores (ANFAVEA), n. 231, agosto de 2005. Disponível em <www.anfavea.com.br>. Acesso em: 04 de agosto de 2005.

11. Doran, J.B.; Aldrich, H.C.; Ingram, L.O. Saccharification and fermentation of sugarcane bagasse by Klebsiella oxytoca P2 containing chromosomally integrated genes encoding the Zymomonas mobilis ethanol pathway. Biotechnol. Bioeng., 44, 240-247, 1994.

12. Golias, H.; Dumsday, G.J.; Stanley, G.A.; Pamment, N.B. Evaluation of a recombinant Klebsiella oxytoca strain for ethanol production from cellulose by simultaneous saccharification and fermentation: comparison with native cellobiose-utilising yeast strains and performance in co-culture with thermotolerant yeast and Zymomonas mobilis. J. Biotechnol., 96, 155-168, 2002.

13. Grohmann, K.; Baldwin, E.A.; Buslig, B.S.; Ingram, L.O. Fermentation of galacturonic acid and other sugars in orange peel hydrolysates by the ethanologenic strain of Escherichia coli. Biotechnol. Lett., 16, 281-286, 1994.

14. Guimarães, W.V.; Dudey, G.D.; Ingram, L.O. Fermentation of sweet whey by ethanologenic Escherichia coli. Biotechnol. Bioeng., 40, 41-45, 1992a.

15. Guimarães, W.V.; Ohta, K.; Burchhard, G.; Ingram, L.O. Ethanol production from starch by recombinant Escherichia coli containing integrated genes for ethanol production and plasmid genes for saccharification. Biotechnol. Lett., 14, 415-420, 1992 b.

16. Hahn-Hägerdal, B.; Jeppsson, H.; Olsson, L.; Mohagheghi, A. An interlaboratory comparison of the performance of ethanol-producing microorganisms in a xylose-rich acid hydrolysate. Appl. Microbiol. Biotechnol., 41, 62-72, 1994.

17. Ingram, L.O.; Conway, T.; Clark, D.P.; Sewell, G.W.; Preston, J.F. Genetic engineering of ethanol production in Escherichia coli. Appl. Environ. Microbiol., 53, 2420-2425, 1987.

18. Kirk, L.A.; Doelle, H.W. The effects of potassium and chloride ions on the ethanolic fermentation of sucrose by Zymomonas mobilis 2716. Appl. Microbiol. Biotechnol., 37, 88-93, 1992.

19. Lawford, H.G., Rousseau, J.D. Fuel ethanol from corn residue prehydrolysate by a patented ethanologenic Escherichia coli. Biotechnol. Lett., 14, 421-426, 1992.

20. Lawford, H.G.; Rousseau, J.D. Loss of ethanologenicity in Escherichia coli B recombinant pLOI297 and KO11 during growth in the absence of antibiotics. Biotechnol. Lett., 17, 751-756, 1995.

21. Leite, A.R.; Guimarâes, W.V.; Araújo, E.F.; Silva, D.O. Fermentation of sweet whey by recombinant Escherichia coli KO11. Braz. J. Microbiol., 31, 212- 215, 2000.

22. Lindsay, S.E.; Bothast, R.J.; Ingram, L.O. Improved strains of recombinant Escherichia coli for ethanol production from sugar mixtures. Appl. Microbiol. Biotechnol., 43, 70-75, 1995.

23. Lynd, L.R.; Cushman, J.H.; Nichols, R.J.; Wyman, C.E. Fuel ethanol from cellulosic biomass. Science. 251, 1318-1323, 1991.

24. Moniruzzaman, M.; Lai, X.; York, S.W.; Ingram, L.O. Extracellular melibiose and fructose are intermediates in raffinose catabolism during fermentation to ethanol by engineered enteric bacteria. J. Bacteriol., 179, 1880-1886, 1997.

25. Ohta, K.; Beall, D.S.; Mejia, J.P.; Shanmugam, K.T.; Ingram, L.O. Genetic improvement of Escherichia coli for ethanol production: chromosomal integration of Zymomonas mobilis genes encoding pyruvate decarboxylase and alcohol dehydrogenase II. Appl. Environ. Microbiol., 57, 893-900, 1991.

26. Olsson, L.; Hahn-Hägerdal, B.; Zacchi, G. Kinetics of ethanol production by recombinant Escherichia coli KO11. Biotechnol. Bioeng., 45, 356-365, 1995.

27. Palha, M.A.P.F.; Lopes, C.E.; Pereira Junior, N. Ethanol stimulates the flocculation of Zymomonas mobilis. Biothecnol. Lett. 19, 499-501, 1997.

28. Sun, Y.; Cheng, J. Hydrolysis of lignocellulosic materials for ethanol production: a review. Bioresource Technol., 83, 1-11, 2002.

29. Tao, H.; Gonzalez, R.; Martinez, A.; Rodriguez, M.; Ingram, L.O.; Preston, J.F.; Shanmugam, K.T. Engineering a homo-ethanol pathway in Escherichia coli: increased glycolytic flux and levels of expression of glycolitic genes during xylose fermentation. J. Bacteriol., 183, 2979-2988, 2001.

30. Underwood, S.A., Buszko, M.L., Shanmugam, K.T., Ingram, L.O. Lack of protective osmolytes limits final cell density and volumetric productivity of ethanologenic Escherichia coli KO11 during xylose fermentation. Appl. Environ. Microbiol., 70, 2734-2740, 2004.

31. Wheals, A.E.; Basso, L.C.; Alves, D.M.G.; Amorim, H.V. Fuel ethanol after 25 years. Trends Biotechnol., 17, 482-487, 1999.

32. Wood, B.E.; Ingram, L.O. Ethanol production from cellobiose, amorphous cellulose, and crystalline cellulose by recombinant Klebsiella oxytoca containing chromosomally integrated Zymomonas mobilis genes for ethanol production and plasmids expressing thermostable cellulase genes from Clostridium thermocellum. Appl. Environ. Microbiol., 58, 2103-2110, 1992. 